\title{
Microsatellite Markers as a Tool for Characterization of Small Ruminants: A Review
}

\author{
Peer Mohmmad Azhar ${ }^{\text {* }}$, D. Chakraborty ${ }^{2}$, Zaffar Iqbal $^{1}$, Abrar A. Malik ${ }^{3}$, \\ Ajaz qaudir ${ }^{3}$, Arshaq Asfar ${ }^{3}$ and Imtiyaz Ahmad Bhat ${ }^{3}$ \\ ${ }^{1}$ Department of Animal Genetics and Breeding, Shuhama, SKUAST-K, India \\ ${ }^{2}$ Department of Animal Genetics and Breeding, R.S. Pura, SKUAST-J, India \\ ${ }^{3}$ Faculty of veterinary science and Animal Husbandary, SKUAST-K, India
}

*Corresponding author

\section{A B S T R A C T}

\begin{tabular}{|l|}
\hline Ke y w o r d s \\
Microsatellite \\
markers, Simple \\
sequence repeats, \\
Molecular \\
characterization
\end{tabular}

Microsatellites are short tandem nucleotide repeats usually 2-6 bp, highly polymorphic in nature, and are found scattered throughout the genome of eukaryotes. Microsatellites are also called short tandem repeats (STR) or simple sequence repeats (SSR), due to the nature of nucleotide repeats which can be mono, di, tri, penta and hexa. They are the most commonest markers used for genetic characterization in various farm animal, which is based on DNA sequence polymorphisms, which are identified by constructing PCR primers for the DNA flanking the microsatellite region. The genetic characterization of domestic animals is part and first step of the FAO for the Management of Farm Animal Genetic Resources. To conserve a population it is important to know how unique or how different it is from other populations. For molecular characterization of native livestock and poultry breeds using microsatellite markers a number of research programs have been undertaken. In order to study animal biodiversity, conservation and management of animal genetic resources the information regarding molecular characterization of indigenous animals very useful.

\section{Introduction}

On the basis of polymorphism occurring at different levels like morphological, biochemical, cellular and DNA level, genetic diversity can be measured. Earlier, blood groups and biochemical polymorphisms were mainly used to study evolutionary relationships in different livestock species (Khanna and Braend, 1968; Khanna, 1979; Schlotterer, 2004). However, with these classical markers it was difficult to measure genetic divergence and gene flow among closely related populations because they possess low discriminating power (VanZeveran et al., 1995; Goldstein and Schlotterer, 1999) the reason behind that was extremely low mutation rates. In genome studies, with the advent of time much attention has been focused on the level of variability at the DNA level. Molecular markers capable of detecting the genetic variation both within coding as well as non-coding sequences of DNA have been developed and has became 
possible to uncover a large number of genetic polymorphisms at the DNA level. The DNA polymorphism as molecular markers uncovered many gates in genetic characterization, improvement, conservation, and molecular evolution studies in different livestock species. For a particular species there are particular genetic markers which are used in estimation of evolutionary history, population subdivision, dispersal, gene flow, effective population size, extended pedigrees, levels of relatedness, breeding structure, etc. (Blot et al., 1998; Goldstein and Schlotterer, 1999) Based on function, genetic markers have divided in two groups (O'Brien, 1992): Type I markers, which are gene based with low degree of polymorphism, but have extensive evolutionary conservation. And Type II markers which are highly, but they are not well conserved between species.

For detecting diversity and breed differentiation a number of techniques are available using molecular markers, including restriction fragment length polymorphisms (RFLP), variable number of tandem repeats (VNTR), denaturing gradient gel electrophoresis (DGGE), single strand conformational polymorphism (SSCP), random amplified polymorphic DNA (RAPD) and microsatellites. Microsatellite makes use of polymorphism of the short tandem repeats. Microsatellites are contributing the most in diversity studies because of their high polymorphic nature, ease of amplification by PCR and abundance in the genome (Dodgson et al., 1997). FAO has recommended 30 microsatellite markers each for Sheep (Table 1) and Goat (Table 2) (FAO, 2011).

\section{History in India}

In India value and need for the characterization and conservation of different livestock genetic resources has been very well realized. National Bureau of Animal Genetic
Resources (NBAGR) which was established in 1984 is considered as the beginning of the efforts for characterization and conservation of livestock genetic resources. At the beginning efforts made by NBAGR and other research groups in India were concentrated on the morphological (Joshi et al., 1995; Nivsarkar et al., 2000; Sahana, 2000; Pundir et al., 2003; Pundir et al., 2004; Verma et al., 2005; Vij et al., 2006) and biochemical marker based (Khanna and Singh, 1970; Singh and Bhat, 1980) characterization of the livestock. However, in 1997, at National Bureau of Plant genetic resources, New Delhi, it was decided that microsatellite markers would be used for molecular characterization of native livestock. In this decision Food and Agricultural Organization (FAO) of the United Nations, made a programme for the global management of genetic resources of various livestock species, in this Project DADIS, MoDAD was formulated, in which suggestion regarding the use of species specific microsatellite loci was made. In diversity analysis it was recommended to use 30 microsatellite loci recommended by FAO.

In the beginning manual genotyping using urea-PAGE was used to study diversity in which allele sizes were determined by running a 10bp ladder along with the samples and by direct counting method genotype of individual was recorded. Sahiwal was first cattle breed among cattle which came in focus (Mukesh et al., 2004). Various research groups in the country started the characterization of their regional breeds (Metta et al., 2004) based on the footprints set by NBAGR. By this manual approach different breeds were characterized. However, manual genotyping being time consuming and cumbersome technique was not very successful. In genetic characterization studies microsatellite markers have become the most frequently used markers among all other markers. In India, almost all the descript breeds of different livestock have been 
characterized by using microsatellite markers. The studies done by (Sodhi et al., 2005 and 2010; Mukesh et al., 2004 and 2006; Sharma et al., 2006; Arora and Bhatia, 2009a and 2009b) have indicated the presence of adequate genetic diversity in the studied Indian native breeds.

\section{Applications of microsatellite markers}

In present days microsatellite markers are the markers of choice for a wide range of molecular genetic studies such as establishing genetic linkage maps (Arora et al., 2004), population structures and mating system analysis.

They are used in the study of genetic variation in vertebrates (Ganai and Yadav, 2001) and in other livestock species viz., poultry, sheep, goats, buffaloes and bovines (Li and Valentini, 2004). These markers are neutral and codominant hence, helps in detection of homozygote and heterozygote genotypes. Gene duplication and deletions can be studied by these markers. They are also ideal for paternity determination, recombination mapping and population genetic studies.

\section{Microsatellite markers in genetic characterization}

Microsatellites are short tandem nucleotide repeats, highly polymorphic in nature and these are found scattered throughout the genome of eukaryotes (Ellegren, 2004). Microsatellites in different farm animals have been used to measure genetic diversity (Handley et al., 2007).

In this the polymorphisms are identified by constructing PCR primers for the DNA flanking the microsatellite region (Hajeer et al., 2000). Useful molecular information has been provided by microsatellite markers that could help in the future management of the small stock breeds (Boettcher et al., 2010). A microsatellite locus varies in length between 5 and 40 repeats, however longer strings of repeats are also possible. For molecular genetic studies dinucleotide, trinucleotide and tetranucleotide repeats are common choices. Among these dinucleotide repeats account for the majority of microsatellites ( $\mathrm{Li}$ et al., 2002).

Trinucleotide and hexanucleotide repeats are likely repeat classes to appear in coding regions as they do not cause a frame shift (Toth et al., 2000). Because of problems with amplification mononucleotide repeats are less reliable (Li et al., 2002). For genetic diversity study microsatellites have become markers of choice (Sunnucks, 2000) and are recommended markers for characterizing various farm animal genetic resources, because of their co-dominant nature and ease of amplification. In the last few decades the development of molecular tools has made an important contribution to characterize variation within and between breeds (Toro et al., 2009).

Useful information for assessing, among other factors, the amount of genetic diversity, the structure of diversity in samples and populations, the rates of genetic divergence among populations and the distribution of diversity in populations found in different locations has been provided by molecular characterization information (Hanotte and Jianlin, 2005; Toro et al., 2009). Molecular characterization has a role in understanding of gene flow, the movement of alleles within and between populations of the same or related species, and its consequences (Toro et al., 2009). Molecular characterization helps in genetic management of small populations, to avoid excessive inbreeding. Information from molecular markers is the basis for improving conservation approaches (Hanotte and Jianlin, 2005). 
Studies carried on molecular characterization of small ruminants (Sheep and Goats) using microsatellites as DNA makers

\section{Studies on sheep}

Arranz et al., (2001) using 18 microsatellites studied genetic variability in five Spanish breeds of sheep viz., Churra, Latxa, Castellana, Rasa-Aragonesa and Merino. About $7 \%$ of total variability of population subdivision was calculated between Spanish breeds from $\mathrm{F}_{\mathrm{ST}}$ diversity indices. From 18 loci a high degree of reliability was obtained for individual-breed assignment using different approaches among which the Bayesian method was most efficient with an accuracy of 9 microsatellites of over $99 \%$.

Alvarez et al., (2004) 14 microsatellites studied genetic relationship among sheep breeds from Northern Spain belonging to 6 sheep breeds determining the relative genetic contributions existing between populations and their historical relationships. In order to assess the existence of underlying genetic structure individual genotypes were analyzed.

Arora and Bhatia (2006) using 25 microsatellite markers studied genetic diversity of Magra sheep breed of India. All used microsatellites were polymorphic. The observed heterozygosity ranged from 0.200 (BM6506) to 0.947 (OarHH35) and the expected heterozygosity ranged from 0.368 (CSSM47) to 0.864 (BM1314). PIC value varied from 0.347 (CSSM47) to 0.849 (BM1314). Inbreeding was reflected by the high average inbreeding coefficient $\left(\mathrm{F}_{\mathrm{IS}}=\right.$ $0.159)$ which is due to the unequal sex ratio of the breeding animals.

Girish et al., (2007) using 25 microsatellite markers studied Genetic variation in Nilagiri sheep. The mean number of observed alleles was 5 across all loci ranging from 3 to 8 . A total of 125 alleles were observed at the 25 loci, all of 25 loci were highly polymorphic. The mean effective number of alleles was 3.84 ranging from 2.18 to 6.49 . The mean PIC value was 0.6485 ranging from 0.4587 to 0.8277. 17 microsatellites were in HardyWeinberg Equilibrium out of all 25. The mean observed and expected heterozygosity was 0.7610 and 0.7213 respectively. Except 6 loci, all other loci showed negative inbreeding estimates $\left(\mathrm{F}_{\mathrm{IS}}\right)$ indicating excess of heterozygotes in the population.

Pandey et al., (2008) using 20 microsatellites studied genetic variability in Rampur Bushair sheep. The overall mean of observed number of alleles was $6.0 \pm 1.91$ ranging from 2 to 9 . The overall mean effective number of alleles was 3.47 \pm 1.29 . The average observed and expected heterozygosity was $0.515 \pm 0.18$ and $0.675 \pm 0.14$. The average $F_{\text {IS }}$ was $0.227 \pm 0.05$ indicated inbreeding in the population.

Pramod et al., (2009) using 25 microsatellite markers studied molecular characterization of Vembur sheep of Tamil Nadu. A total of 147 alleles were found, with a mean of $5.88 \pm 0.29$ alleles per locus. The mean effective number of alleles observed was $4.0950 \pm 0.23$ alleles per locus and mean PIC value was $0.6905 \pm 0.02$. The mean observed and expected heterozygosity $\left(\mathrm{H}_{0}\right)$ values were $0.5202 \pm 0.04$ and $0.7339 \pm 0.02$ respectively, varied between 0.1333 to 1.0000 and 0.4847 to 0.8537 respectively. Negative values of FIS for three loci indicated more heterozygous nature of the population.

Sharma et al., (2010) using 25 microsatellite markers studied genetic diversity in Changthangi sheep. 219 alleles in total were detected. All the Microsatellite markers were highly polymorphic, with mean of observed number of alleles was $8.760 \pm 0.587$ ranging from 4 to 15 per locus. The mean of expected 
number of alleles was $4.539 \pm 0.412$ ranging from 1.144 (CSSM47) to 10.509 (OarCP49). The mean observed heterozygosity was $0.691 \pm 0.039$ ranging from 0.053 (CSSM47) to 0.912 (OarCP49) which indicates the presence of substantial amount of genetic variability in the sheep breed.

Zhong et al., (2011) using 26 microsatellites studied the genetic diversity and structure of Mongolian sheep in China. The Bayesian clustering was done which indicated five clusters as the most probable genetic structure of the populations. In three populations distributed at large geographical scales a clear genetic structure was revealed, while the other cluster encompassed UQ and HLBR sheep that displayed no clear differentiation, which may be due to their close and small geographical distributions.

Hoda and Marsan (2012) using 31 microsatellite markers recommended by $\mathrm{MoDAD} / \mathrm{FAO}$ studied genetic characterization, genetic diversity, genetic relationship and structure of local sheep in Albania. Raja et al., (2012) using 24 Microsatellite markers studied genetic diversity in Ramnad White sheep. GENEMAPPER software was used for allele sizing.

Yadav and Arora (2014) based on microsatellite markers studied the genetic differentiation in Muzaffarnagri and Munjal sheep. Microsatellite markers data showed high level of allelic richness (>6.0) and genetic diversity $(>0.7)$ for both breeds/populations. Bayesian cluster analysis was done which indicated distinct clusters with an average membership coefficient of 0.974 for Muzaffarnagri and 0.972 for Munjal sheep.

Kavitha et al., (2015) using 25 microsatellite markers studied genetic characterisation of
Tiruchy Black sheep of Tamil Nadu. A total of 203 alleles were observed. The mean number of alleles observed was 8.12 \pm 0.45 ranging from 4 (OarHH41) to 13 (OarHH35). The mean effective number of alleles was $4.48 \pm 0.27$ ranging from 1.59 (OarHH41) to 7.51 (OarHH35). The mean PIC was $0.8441 \pm 0.012$ ranging from 0.7029 (OarHH41) to 0.9164 (OarHH35). As per $\chi 2$ test only 10 among the 25 microsatellites studied were in Hardy-Weinberg Equilibrium proportions.

Sassi-Zaidy et al., (2016) using microsatellite markers studied genetic diversity and genetic relationship of the two groups of African sheep, thin-tailed and fat-tailed sheep, represented by the indigenous Tunisian sheep breeds Barbarine (BAR, fat-tailed) and Queue Fine de Ouest (QFO, thin-tailed). The mean of observed heterozygosity was 0.719 and mean of expected heterozygosity was 0.789 . A notable level of inbreeding within the whole population was seen described by average $\mathrm{F}_{\text {IS }}$ $(0.112)$ and $\mathrm{F}_{\text {IT }}(0.118)$ values.

\section{Studies on goat}

Ganai and Yadav (2001) using 16 microsatellite markers studied the genetic dsistance and variation in three Indian goat breeds. The mean value of heterozygosity was $0.54 \pm 0.2$ and PIC value was $0.4 \pm 0.20$. The study showed the closer relationship between Jamnapari and Barbari goat breeds.

Kim et al., (2002) using microsatellites analysed the genetic diversity of the three domestic goat breeds Korean goat, Chinese goat and Saanen found in Korea and China. The expected mean heterozygosity, were $\mathrm{H}_{\mathrm{e}}=0.381$ (Korean goat), and $\mathrm{H}_{\mathrm{e}}=0.669$ (Chinese goat). The results showed genetic differentiation between Korean goat and the other two breeds, indicating that these breeds have been genetically subdivided. 
Int.J.Curr.Microbiol.App.Sci (2018) 7(1): 1330-1342

Table.1 Recommended microsatellite markers for sheep

\begin{tabular}{|c|c|c|c|}
\hline Name(s) & Chromosome & Primer sequence $\left(5^{\prime}->3^{\prime}\right)$ Forward Reverse & $\begin{array}{c}\text { Annealing } \\
\text { temperature } \\
\left({ }^{\circ} \mathbf{C}\right)\end{array}$ \\
\hline OarFCB128 & OAR2 & $\begin{array}{l}\text { ATTAAAGCATCTTCTCTTTATTTCCTCGC } \\
\text { CAGCTGAGCAACTAAGACATACATGCG }\end{array}$ & 55 \\
\hline OarCP34 & OAR 3 & $\begin{array}{l}\text { GCTGAACAATGTGATATGTTCAGG } \\
\text { GGGACAATACTGTCTTAGATGCTGC }\end{array}$ & 50 \\
\hline OarCP38 & OAR 10 & $\begin{array}{l}\text { CAACTTTGGTGCATATTCAAGGTTGC } \\
\text { GCAGTCGCAGCAGGCTGAAGAGG }\end{array}$ & 52 \\
\hline OarHH47 & OAR 18 & $\begin{array}{l}\text { TTTATTGACAAACTCTCTTCCTAACTCCACC } \\
\text { GTAGTTATTTAAAAAAATATCATACCTCTTAAGG }\end{array}$ & 58 \\
\hline OarVH72 & OAR 25 & $\begin{array}{l}\text { GGCCTCTCAAGGGGCAAGAGCAGG } \\
\text { CTCTAGAGGATCTGGAATGCAAAGCTC }\end{array}$ & 57 \\
\hline OarAE129 & OAR 5 & $\begin{array}{l}\text { AATCCAGTGTGTGAAAGACTAATCCAG } \\
\text { GTAGATCAAGATATAGAATATTTTTCAACACC }\end{array}$ & 54 \\
\hline BM1329 & OAR 6 & $\begin{array}{l}\text { TTGTTTAGGCAAGTCCAAAGTC } \\
\text { AACACCGCAGCTTCATCC }\end{array}$ & 50 \\
\hline BM8125 & OAR 17 & $\begin{array}{l}\text { CTCTATCTGTGGAAAAGGTGGG } \\
\text { GGGGGTTAGACTTCAACATACG }\end{array}$ & 50 \\
\hline HUJ616 & OAR 13 & $\begin{array}{l}\text { TTCAAACTACACATTGACAGGG } \\
\text { GGACCTTTGGCAATGGAAGG }\end{array}$ & 54 \\
\hline DYMS1 & OAR 20 & $\begin{array}{l}\text { AACAACATCAAACAGTAAGAG } \\
\text { CATAGTAACAGATCTTCCTACA }\end{array}$ & 59 \\
\hline SRCRSP9 & CHI12 & $\begin{array}{l}\text { AGAGGATCTGGAAATGGAATC } \\
\text { GCACTCTTTTCAGCCCTAATG }\end{array}$ & 55 \\
\hline OarCB226 & OAR 2 & $\begin{array}{l}\text { CTATATGTTGCCTTTCCCTTCCTGC } \\
\text { GTGAGTCCCATAGAGCATAAGCTC }\end{array}$ & 60 \\
\hline ILSTS5 & OAR 7 & $\begin{array}{l}\text { GGAAGCAATGAAATCTATAGCC } \\
\text { TGTTCTGTGAGTTTGTAAGC }\end{array}$ & 55 \\
\hline ILSTS11 & OAR 9 & $\begin{array}{l}\text { GCTTGCTACATGGAAAGTGC } \\
\text { CTAAAATGCAGAGCCCTACC }\end{array}$ & 55 \\
\hline ILSTS28 & OAR 3 & $\begin{array}{l}\text { TCCAGATTTTGTACCAGACC } \\
\text { GTCATGTCATACCTTTGAGC }\end{array}$ & 53 \\
\hline SRCRSP5 & OAR 18 & $\begin{array}{l}\text { GGACTCTACCAACTGAGCTACAAG } \\
\text { GTTTCTTTGAAATGAAGCTAAAGCAATGC }\end{array}$ & 56 \\
\hline MAF214 & OAR 16 & $\begin{array}{l}\text { GGGTGATCTTAGGGAGGTTTTGGAGG } \\
\text { AATGCAGGAGATCTGAGGCAGGGACG }\end{array}$ & 58 \\
\hline SRCRSP1 & CHI13 & $\begin{array}{l}\text { TGCAAGAAGTTTTTCCAGAGC } \\
\text { ACCCTGGTTTCACAAAAGG }\end{array}$ & 54 \\
\hline MAF33 & OAR 9 & $\begin{array}{l}\text { GATCTTTGTTTCAATCTATTCCAATTTC } \\
\text { GATCATCTGAGTGTGAGTATATACAG }\end{array}$ & 60 \\
\hline MCM140 & OAR 6 & $\begin{array}{l}\text { GTTCGTACTTCTGGGTACTGGTCTC } \\
\text { GTCCATGGATTTGCAGAGTCAG }\end{array}$ & 60 \\
\hline OarFCB20 & OAR 2 & $\begin{array}{l}\text { AAATGTGTTTAAGATTCCATACAGTG } \\
\text { GGAAAACCCCCATATATACCTATAC }\end{array}$ & 56 \\
\hline OarFCB193 & OAR 11 & $\begin{array}{l}\text { TTCATCTCAGACTGGGATTCAGAAAGGC } \\
\text { GCTTGGAAATAACCCTCCTGCATCCC }\end{array}$ & 54 \\
\hline OarFCB304 & OAR 19 & $\begin{array}{l}\text { CCCTAGGAGCTTTCAATAAAGAATCGG } \\
\text { CGCTGCTGTCAACTGGGTCAGGG }\end{array}$ & 56 \\
\hline OarJMP29 & OAR 24 & $\begin{array}{l}\text { GTATACACGTGGACACCGCTTTGTAC } \\
\text { GAAGTGGCAAGATTCAGAGGGGAAG }\end{array}$ & 56 \\
\hline OarJMP58 & OAR 26 & $\begin{array}{l}\text { GAAGTCATTGAGGGGTCGCTAACC } \\
\text { CTTCATGTTCACAGGACTTTCTCTG }\end{array}$ & 58 \\
\hline MAF65 & OAR 15 & $\begin{array}{l}\text { AAAGGCCAGAGTATGCAATTAGGAG } \\
\text { CCACTCCTCCTGAGAATATAACATG }\end{array}$ & 60 \\
\hline MAF70 & OAR 4 & $\begin{array}{l}\text { CACGGAGTCACAAAGAGTCAGACC } \\
\text { GCAGGACTCTACGGGGCCTTTGC }\end{array}$ & 60 \\
\hline MAF209 & OAR 17 & $\begin{array}{l}\text { GATCACAAAAAGTTGGATACAACCGTGG } \\
\text { TCATGCACTTAAGTATGTAGGATGCTG }\end{array}$ & 63 \\
\hline BM1824 & OAR 1 & $\begin{array}{l}\text { GAGCAAGGTGTTTTTCCAATC } \\
\text { CATTCTCCAACTGCTTCCTTG }\end{array}$ & 58 \\
\hline INRA063 & OAR 14 & $\begin{array}{l}\text { ATTTGCACAAGCTAAATCTAACC } \\
\text { AAACCACAGAAATGCTTGGAAG }\end{array}$ & 58 \\
\hline
\end{tabular}


Table. 2 Recommended microsatellite markers for goat

\begin{tabular}{|c|c|c|c|}
\hline Name(s) & Chromosome & Primer sequence $\left(5^{\prime}->3^{\prime}\right)$ Forward Reverse & $\begin{array}{l}\text { Annealing } \\
\text { Temperature }\left({ }^{\circ} \mathbf{C}\right)\end{array}$ \\
\hline SRCRSP5 & CHI21 & $\begin{array}{l}\text { GGACTCTACCAACTGAGCTACAAG } \\
\text { TGAAATGAAGCTAAAGCAATGC }\end{array}$ & 55 \\
\hline MAF065 & OAR15 & $\begin{array}{l}\text { AAAGGCCAGAGTATGCAATTAGGAG } \\
\text { CCACTCCTCCTGAGAATATAACATG }\end{array}$ & 58 \\
\hline MAF70 & BTA4 & $\begin{array}{l}\text { CACGGAGTCACAAAGAGTCAGACC } \\
\text { GCAGGACTCTACGGGGCCTTTGC }\end{array}$ & 65 \\
\hline SRCRSP23 & unknown & $\begin{array}{l}\text { TGAACGGGTAAAGATGTG } \\
\text { TGTTTTTAATGGCTGAGTAG }\end{array}$ & 58 \\
\hline OarFCB48 & OAR17 & $\begin{array}{l}\text { GAGTTAGTACAAGGATGACAAGAGGCAC } \\
\text { GACTCTAGAGGATCGCAAAGAACCAG }\end{array}$ & 58 \\
\hline INRA023 & BTA3 & $\begin{array}{l}\text { GAGTAGAGCTACAAGATAAACTTC } \\
\text { TAACTACAGGGTGTTAGATGAACT }\end{array}$ & 58 \\
\hline SRCRSP9 & CHI12 & $\begin{array}{l}\text { AGAGGATCTGGAAATGGAATC } \\
\text { GCACTCTTTTCAGCCCTAATG }\end{array}$ & 58 \\
\hline OarAE54 & OAR25 & $\begin{array}{l}\text { TACTAAAGAAACATGAAGCTCCCA } \\
\text { GGAAACATTTATTCTTATTCCTCAGTG }\end{array}$ & 58 \\
\hline SRCRSP8 & Unknown & $\begin{array}{l}\text { TGCGGTCTGGTTCTGATTTCAC } \\
\text { GTTTCTTCCTGCATGAGAAAGTCGATGCTTAG }\end{array}$ & 55 \\
\hline SPS113 & BTA10 & $\begin{array}{l}\text { CCTCCACACAGGCTTCTCTGACTT } \\
\text { CCTAACTTGCTTGAGTTATTGCCC }\end{array}$ & 58 \\
\hline INRABERN172 & BTA26 & $\begin{array}{l}\text { CCACTTCCCTGTATCCTCCT } \\
\text { GGTGCTCCCATTGTGTAGAC }\end{array}$ & 58 \\
\hline OarFCB20 & OAR2 & $\begin{array}{l}\text { GGAAAACCCCCATATATACCTATAC } \\
\text { AAATGTGTTTAAGATTCCATACATGTG }\end{array}$ & 58 \\
\hline CSRD247 & OAR14 & $\begin{array}{l}\text { GGACTTGCCAGAACTCTGCAAT } \\
\text { CACTGTGGTTTGTATTAGTCAGG }\end{array}$ & 58 \\
\hline McM527 & OAR5 & $\begin{array}{l}\text { GTCCATTGCCTCAAATCAATTC } \\
\text { AAACCACTTGACTACTCCCCAA }\end{array}$ & 58 \\
\hline ILSTS087 & BTA6 & $\begin{array}{l}\text { AGCAGACATGATGACTCAGC } \\
\text { CTGCCTCTTTTCTTGAGAG }\end{array}$ & 58 \\
\hline INRA063 & CHI18 & $\begin{array}{l}\text { GACCACAAAGGGATTTGCACAAGC } \\
\text { AAACCACAGAAATGCTTGGAAG }\end{array}$ & 58 \\
\hline ILSTS011 & BTA14 & $\begin{array}{l}\text { GCTTGCTACATGGAAAGTGC } \\
\text { CTAAAATGCAGAGCCCTACC }\end{array}$ & 58 \\
\hline LSTS005 & BTA10 & $\begin{array}{l}\text { GGAAGCAATTGAAATCTATAGCC } \\
\text { TGTTCTGTGAGTTTGTAAGC }\end{array}$ & 55 \\
\hline SRCRSP15 & Unknown & $\begin{array}{l}\text { CTTTACTTCTGACATGGTATTTCC } \\
\text { TGCCACTCAATTTAGCAAGC }\end{array}$ & 55 \\
\hline SRCRSP3 & CHI10 & $\begin{array}{l}\text { CGGGGATCTGTTCTATGAAC } \\
\text { TGATTAGCTGGCTGAATGTCC }\end{array}$ & 55 \\
\hline ILSTS029 & BTA3 & $\begin{array}{l}\text { TGTTTTGATGGAACACAG } \\
\text { TGGATTTAGACCAGGGTTGG }\end{array}$ & 55 \\
\hline TGLA53 & BTA16 & $\begin{array}{l}\text { GCTTTCAGAAATAGTTTGCATTCA } \\
\text { ATCTTCACATGATATTACAGCAGA }\end{array}$ & 55 \\
\hline ETH10 & CHI5 & $\begin{array}{l}\text { GTTCAGGACTGGCCCTGCTAACA } \\
\text { CCTCCAGCCCACTTTCTCTTCTC }\end{array}$ & 55 \\
\hline MAF209 & CHI17 & $\begin{array}{l}\text { GATCACAAAAAGTTGGATACAACCGTG } \\
\text { TCATGCACTTAAGTATGTAGGATGCTG }\end{array}$ & 55 \\
\hline INRABERN185 & CHI18 & $\begin{array}{l}\text { CAATCTTGCTCCCACTATGC } \\
\text { CTCСТАAАACАСТСССАСАСТА }\end{array}$ & 55 \\
\hline$\overline{\text { P19 (DYA) }}$ & Unknown & $\begin{array}{l}\text { AACACCATCAAACAGTAAGAG } \\
\text { CATAGTAACAGATCTTCCTACA }\end{array}$ & 55 \\
\hline$\overline{\text { TCRVB6 }}$ & BTA10 & $\begin{array}{l}\text { GAGTCCTCAGCAAGCAGGTC } \\
\text { CCAGGAATTGGATCACACCT }\end{array}$ & 55 \\
\hline SRCRSP7 & CHI6 & $\begin{array}{l}\text { TCTCAGCACCTTAATTGCTCT } \\
\text { GGTCAACACTCCAATGGTGAG }\end{array}$ & 55 \\
\hline BM6444 & BTA2 & $\begin{array}{l}\text { CTCTGGGTACAACACTGAGTCC } \\
\text { TAGAGAGTTTCCCTGTCCATCC }\end{array}$ & 65 \\
\hline DRBP1 & BTA23 & $\begin{array}{l}\text { ATGGTGCAGCAGCAAGGTGAGCA } \\
\text { GGGACTCAGTCTCTCTATCTCTTTG }\end{array}$ & 58 \\
\hline
\end{tabular}


Kotze et al., (2004) using 18 microsatellite markers analyzed genetic diversity of Kalahari goat breed from South Africa and studying dilution of the Kalahari Red with Red Boer goats. The genetic characterization information formed the basis for future management of Kalahari Red goat.

Kumar et al., (2005) using 25 microsatellite loci studied population structure and genetic bottleneck hypothesis on Marwari goats in Rajasthan. The genetic variation was seen in terms of effective number of alleles and gene diversities observed. The average polymorphism across the studied loci was 1.295 and the expected gene diversity in the population was $0.623 \pm 0.041$. The population, showed a good level of inbreeding $\left(F_{I S}=0.264 \pm 0.046\right)$ and was observed to be significantly differentiated into groups.

Gour et al., (2006) using 23 microsatellite loci studied the genetic distance of Jamunapari goats. The overall mean number of alleles observed was $4.913 \pm 1.905$ ranging from 2 to 10. Average polymorphism and expected gene diversity were $1.066 \pm 0.510$ and $0.528 \pm 0.237$ respectively. The population structure and genetic bottleneck hypothesis were examined. Population showed fairly high level of inbreeding $\left(F_{I S}=0.189 \pm 0.049\right)$ and heterozygote deficit.

Oliveira et al., (2007) based on microsatellites studied genetic distance, structure and relationships between Brazilian naturalized and exotic purebred domestic goat breeds (Capra hircus). By using 13 microsatellites genetic relationships and structure of 14 goat (Capra hircus) populations were estimated. All 13 loci were polymorphic with an average of 15.6 alleles per locus.

Dixit et al., (2008) using 25 microsatellite markers studied genetic distance on Kutchi, Mehsana and Sirohi goat breeds of India.
Among the 3 breeds, the Mehsana breed showed lowest genetic diversity. An overall significant heterozygote deficit was present in all the populations. The FIS values for Kutchi, Mehsana and Sirohi goat breeds were 0.26, 0.14 and 0.36 respectively.

Ramamoorthi et al., (2009) using 21 microsatellite markers studied genetic characterization and conservation on Barbari goats. The number of alleles ranged from 4 to 11 and allele frequencies was between 0.0104 and 0.5208 . PIC values ranged from 0.5563 to 0.8348. Except for two microsatellite loci (ILSTS044 and ILSTS060), for all others the population was not in Hardy-Weinberg equilibrium. The observed and expected heterozygosities ranged from 0.8478 to 1.0000 and 0.6208 to 0.8509 respectively.

Verma et al., (2010) using 25 microsatellite markers studied the genetic variability by phenotypic and genetic characterization of Sangamneri goat breed. The overall mean of number of alleles observed was 9.0 ranging from 3 (ILSTS 022) to 21 (OarFCB304). The average PIC value was 0.711 ranging from 0.271 (OarJMP29) to 0.878 (ILSTS 082). The mean expected and observed gene diversity within the population was $0.6970 \pm 0.033$ and $0.5399 \pm 0.0549$ respectively. Out of 25 loci 16 showed significant heterozygote deficiency.

Dixit et al., (2011) using 25 microsatellite studied genetic variation in Kanniadu goats of Tamil Nadu. The average of observed number of alleles was $8.64 \pm 0.48$ ranging from 5 (RM4) to 13 (RM088, OarE129).

The overall mean effective number of alleles was 4.22 \pm 0.34 ranging from 1.45 (ILSTS34) to 7.89 (ILSTS033 and OMHC1). The mean observed heterozygosity was $0.53 \pm 0.03$ and expected heterozygosity was $0.73 \pm 0.02$. High PIC values (0.30 to 0.86) indicated higher polymorphism in the breed. 
Rout et al., (2012) using 17 microsatellite loci studied genetic diversity on Jamunapari goat. The mean number of alleles per locus and the mean heterozygosity was 9.0 and 0.769 respectively, indicating high allelic variation. On comparison to 10 other Indian goat breeds the gene diversity and effective number of alleles were higher. In this study the genetic diversity of Y-chromosome genes was low.

Zaman et al., (2013) using 23 microsatellite markers studied genetic diversity and population structure in Assam hill goats. All the loci under study were polymorphic. The overall mean of observed number of alleles (Na) was 4.9 \pm 2.220 ranging from 2 to 10 . The mean effective number of alleles $(\mathrm{Ne})$ was $2.68 \pm 1.590$ ranging from 1.035 to 7.127 . The overall mean observed heterozygosity $\left(\mathrm{H}_{\mathrm{o}}\right)$ was 0.43 and expected heterozygosity $\left(\mathrm{H}_{\mathrm{e}}\right)$ was 0.48 .

Singh et al., (2014) using 15 microsatellite markers studied genetic characterization of Gaddi goat. A total of 135 distinct allele were observed. The mean observed and effective number of alleles was $9.0000 \pm 0.82$ and $6.5874 \pm 0.56$ respectively. The mean observed (HO) heterozygosity was $0.7484 \pm 0.02$ and mean expected (HE) heterozygosity was $0.8431 \pm 0.01$.

Kharkar et al., (2015) using micro-satellite markers studied the genetic variability in Berari goat breed The average observed number of alleles was $15.560 \pm 0.947$ ranging from 9 (ILSTS059, RM004) to 25 (ILSTS005, ILSTS029). The mean effective number of alleles was $10.214 \pm 0.602$ ranging from 6.036 (RM088) to 16.736 (ILSTS029). The average expected gene diversity within the population was $0.895 \pm 0.006$ ranging from 0.834 (RM004) to 0.940 (ILSTS029). All the loci under study showed the polymorphic information content value greater than 0.5 indicating higher polymorphism in the breed.
Seilsuth et al., (2016) using 12 microsatellite markers analysed the genetic relationships between different populations and breeds of exotic dairy goats in Thailand. Out of 12 microsatellite markers 5 were found to be polymorphic. A total of 37 alleles were present in all breeds with a mean of 7.40 alleles per locus, ranging from 5 (SPS115 and ETH225) to 11 (TGLA122). Mean expected heterozygosity value was 0.539 and the average observed heterozygosity was 0.529 showing genetic variability within the breeds was moderate.

Microsatellites markers are highly polymorphic DNA markers, they are highly abundant, very simply to analyze and easy to score, but nevertheless these types of markers have disadvantages such as null alleles, or size homoplasy (Schlotterer, 2004). Microsatellites are the most informative molecular marker with the advantage of easy and low-cost detection by PCR, because of high mutation rate. Another great advantage of microsatellites is their co-dominant feature and hence detect both homozygote and heterozygote genotypes, unlike RAPD and AFLP markers, which are dominant markers detecting only the presence or absence of a locus.

\section{References}

Alvarez, I., Royo, L. J., Fernandez, I., Gutierrez, J. P., Gomez, E. and Goyache, F. 2004. Genetic relationships and admixture among sheep breeds from Northern Spain assessed using microsatellites. Asian-Aust. J. Anim. Sci., 82(8): 2246-2252.

Arora, R. and Bhatia, S. 2006. Genetic Diversity of Magra Sheep from India Using Microsatellite analysis. AsianAust. J. Anim. Sci., 19(7): 938 - 942.

Arora, R. and Bhatia, S. 2009a. Evaluation of genetic effects of demographic 
bottleneck in Muzzaffarnagari sheep from India using microsatellite markers. Asian Australian Journal of Animal Sciences, 22: 1-6.

Arora, R. and Bhatia, S. 2009b. Genetic diversity analysis of three Indian sheep breeds using microsatellite markers. Journal of Livestock Biodiversity, 1: $18-24$.

Arora, R., Lakhchaura, B. D., Prasad, R. B., Tantia, M. S. and Vijh, R. K. 2004. Genetic diversity analysis of two buffalo populations of northern India using microsatellite markers. Journal of Animal Breeding and Genetics, 121: 111-118.

Arranz, J. J., Bayon, Y. and SanPrimitivo, F. 2001. Differentiation among Spanish sheep breeds using microsatellites. Genet. Sel. Evol., 33: 529-542.

Blot, S. C., Williams J. L. and Haley. C. S. 1998. Genetic variation within the Hereford breed of cattle. Anim. Genet. 29: 202-211.

Boettcher, P. J., Ajmone-Marsan, P. and Lenstra, J. A. 2010. Recent Development in the genetic characterisation of animal genetic resources. Animal Genetic Resources Branch, FAO- AGA, 00153 Rome, Italy.

Dixit S. P., Verma, N. K., Ahlawat, S. P. S., Aggarwal, R. A. K., Kumar, S., Chander, R and Singh, K. P. 2008. Molecular genetic characterization of Kutchi breed of goat. Curr. Sci., 95(7): 946-952.

Dixit, S. P., Verma, N. K., Aggarwal, R. A. K., Vyas, M. K., Rana, J., Sharma, A. and Chander. R. 2011. Genetic variability and bottleneck analyses of kanniadu goat breed based on microsatellite markers. Indian J. Anim. Sci., 81(1): 43-48.

Dodgson, J. B., Cheng, H. H and Okimoto, R. L. 1997. DNA marker technology: a revolution in animal genetics. Poultry Science, 76:1108-1113.

Ellegren, H. 2004. Microsatellites: Simple Sequences with complex Evolution. Nature Reviews, 5: 435-445.

FAO, 2000. In: Scherf, B. (ed), World Watch List for Domestic Animal Diversity, 3 ed., Rome.

FAO. 2011. Draft guidelines on molecular genetic characterization of animal genetic resources. http;//www.fao.org/ dad-is/

Ganai, N. A. and Yadav, B. R. 2001. Genetic variation within and among three Indian breeds of goat using heterologous microsatellite markers. Animal Biotechnology, 12: 121-36.

Ganai, N. A. and Yadava, B. R. 2001. Genetic variation within and among three Indian goat breeds using heterologous microsatellite markers. Anim. Biotechnol., 12(2): 121-136.

Girish, H., Sivaselvam, S. N., Karthikeyan, S. M. K. and Saravanan, R. 2007. Molecular characterisation of Nilagiri sheep (Ovis aries) of south India based on microsatellites. Asian-Aust. J. Anim. Sci., 20 (5): 633-637.

Goldstein, D. B. and Schlotterer, C. 1999. Microsatellites: Evolution and Applications. Oxford University Press.

Gour, D. S., G. Malik, S. P. S, Ahlawat, A. K. Pandey, R. Sharma, N. Gupta, S. C. Gupta, P. S. Bisen, and D. Kumar. 2006. Analysis of genetic structure of Jamunapari goats by microsatellite markers. Small Rumin. Res, 66: 140149.

Hajeer, A., Worthington, J. and John, S. (eds.). 2000. SNP and Microsatellite Genotyping: Markers for Genetic Analysis. Biotechniques: Molecular Laboratory Methods Series. Eaton Publishing, Manchester, UK.

Hanotte, O. and Jianlin, H. 2005. Genetic characterisation of livestock populations 
and its use in conservation decisionmaking. In J. Ruane and A. Sonnino, eds. The role of biotechnology in exploring and protecting agricultural genetic resources, Pp. 89-96.

Hoda, A. and Marsan, P. A. 2012. Genetic Characterization of Albanian Sheep Breeds by Microsatellite Markers. http://cdn.intechweb.org/pdfs/29252.pdf

Joshi, B. K., Tantia, M. S., Kumar, P., Gupta, N., Vij, P. K., Nivsarkar, A. E. and Sahai, R. 1995. Hariana cattle A Monograph on Breed characteristics. National Bureau of Animal Genetic Resources, Karnal, India Research Bulletin No. 3 .

Kavitha, S. T., Subramanian, A., Sivaselvam, S.N., Thiagarajan, R. and Balasubramanian, S. 2015. Genetic characterisation of Tiruchy Black sheep of Tamil Nadu using microsatellite markers. Indian J. Anim. Res., 49 (3): 320-324.

Khanna, N. D. 1979. A note on electrophoretic study on the haemoglobin of Indian buffaloes. Indian Journal of Animal Sciences, 49: 23134.

Khanna, N. D. and Braend, M. 1968. Haemoglobin and albumin polymorphism in India water ialoes. Acta veterinaria Scaninavia, 9: 316327.

Khanna, N. D. and Singh, H. P. 1970. Studies on biochemical polymorphism in bovines. 1. Haemoglobin variations in Hariana breed of cattle. Journal of Genetics, 60: 159-63.

Kharkar, K., Kuralkar, S. V. and Kuralkar, P. 2015. Molecular genetic characterization of Berari breed of goat using microsatellite markers. Indian J. Anim. Res., 49(4): 423-428.

Kim, K. S., Yeo, J. S., Lee, J. W., Kim, J. W. and Choi, C. B. 2002. Genetic diversity of goats from Korea and China using microsatellite analysis. Asian-Aust. J. Anim. Sci., 15(4): 461-465.

Kotze, A., Swart, H, Grobler, J. P. and. Nemaangani, A. 2004. A genetic profile of the Kalahari Red goat breed from southern Africa. South African Journal of Animal Science, 34(1).

Kumar, D., Dixit, S. P., Sharma, R., Pandey, A. K., Sirohi, G., Patel, A. K., Aggarwal, R. A. K., Verma, N. K., Gour, D. S. and Ahlawat, S. P. S. 2005. Population structure genetic variation and management of Marwari goats. Small Ruminant Research, 59:41-48.

Li, X.L. and Valentini, A. 2004. Genetic diversity of Chinese indigenous goat breeds based on microsatellite markers. J Anim Breed Genet., 121(5): 350-355.

Li, Y. C., Korol, A. B., Fahima, T., Beiles, A. and Nevo. E. 2002. Microsatellites: genomic distribution, putative functions and mutational mechanisms: a review. Molecular Ecology, 11: 2453-2465.

Metta, M., Kanginakudru, S., Gudiseva, N. and Nagaraju, J. 2004. Genetic characterization of the Indian cattle breeds, Ongole and Deoni Bos indicus using microsatellite markers - a preliminary study. BMC Genetics, 5: 516.

Mukesh, M., Sodhi, M. and Bhatia, S. 2006. Microsatellite based diversity analysis and genetic relationships of three Indian sheep breeds. Journal of Animal Breeding and Genetics, 123: 258- 264.

Mukesh, M., Sodhi, M., Mishra, B. P., Vij, P. K., Tantia, M. S. and Bhatia, S. 2004. Assessment of population structure and microsatellite based genetic variability in Sahiwal cattle. Indian Journal of Animal Sciences, 74: 1051-1055.

Nivsarkar, A. E., Vij, P. K. and Tantia, M. S. 2000. Animal Genetic Resources of India Cattle and Buffalo. Directorate of Information and Publications of 
Agriculture, Indian Council of Agricultural Research, New Delhi.

O'Brien, S. J. 1992. Mammalian genome mapping lessons and prospects. Current Opinion in Genetics and Development, 1: $105-11$.

Oliveira, J. D., Igarashi, M. L. S. P., Machado, T. M.M., Miretti, M. M., Ferro, J. A. and Contel, E. P. B. C. 2007. Structure and genetic relationships between Brazilian naturalized and exotic purebred goat (Capra hircus) breeds based on microsatellites. Genetic and Molecular Biology, 30(2): 356-263.

Pandey, A. K., Sharma, R., Singh, Y. and Mishra, B. P. 2008. Genetic Variability in Rampur Bushair sheep breed using microsatellite markers. Indian Journal of Animal Sciences, 78(6): 623-62.

Pramod, S., Kumarasamy, P., Chandra, A. R. M., Sridevi, P. and Rahumathulla, P. S. 2009. Molecular characterization of Vembur sheep (Ovis aries) of south India based on microsatellites. Indian Journal of Science and Technology, 2(11): 55-58.

Pundir, R. K. and Ahlawat, S. P. S. 2003. Bhadawari buffaloes unique germplasm for high milk fat. Livestock International, 8: 217.

Pundir, R. K. and Ahlawat, S. P. S. 2004. Kankrej cattle: A useful draft and milch breed of Gujarat. Livestock International, 8: 21-23.

Raja, K. N., Jain, A., Singh, G., Kumar, L., Yadav, H. K. and Arora, R. 2012. Ramnad White sheep-Phenotypic and genetic characterization. Indian Journal of Animal Sciences, 82(9): 1082-1086.

Ramamoorthi, J., K. Thilagam, S. N. Sivaselvam, and S. M. Karthickeyan. 2009. Genetic characterization of Barbari goats using microsatellite markers. J. Vet. Sci. 10: 73-76.

Rout, P. K, Thangraj, K, Mandal, A. and Roy,
R. 2012. Genetic variation and population structure in Jamunapari goats using microsatellites, mitochondrial DNA, and milk protein genes. The Sci. World J., 2012: 618909.

Sahana, G. 2000. Sheep and goat genetic resources of India. Research, 54: 22730.

Sassi-Zaidy, Y. B., Maretto, F., CharfiCheikhrouha, F., Mohamed-Brahmi, A. and Cassandro, M. 2016. Contribution of microsatellites markers in the clarification of the origin, genetic risk factors, and implications for conservation of Tunisian native sheep breeds. Genetics and Molecular Research, 15(1): gmr.15017059. http://dx.doi.org/10.4238/gmr.15017059

Schlotterer. 2004. The evolution of molecular markers: just a matter of fashion. Nature Reviews, 5: 63-69.

Seilsuth, S., Seo, J. H., Kong, H. S. and Jeon, G. J. 2016. Microsatellite Analysis of the Genetic Diversity and Population Structure in Dairy Goats in Thailand. Asian Australas. J. Anim. Sci., 29(3): 327-332.

Sharma, R., Pandey, A. K., Kumar, D., Jain, A., Malik, G., Gaur, D. S. and Ahlawat, S. P. S. 2006. Genetic variation analysis of Hassan sheep population using microsatellite markers. Korean Journal of Genetics, 28: 43-51.

Sharma, R., Pandey, A. K., Singh, L. V., Maitra, A., Arora, R., Bhaitia, S. and Mishra, B. P. 2010. Microsatellite based diversity estimation of Changthangi-a high altitude sheep breed of India. Indian Journal of Animal Sciences, 80(5): 436-40.

Singh, G., Thakur, Y., Kour, A., Sankhyan, V. and Katoch S. 2014. Genetic characterization of Gaddi goat breed of Western Himalayas using microsatellite markers, Veterinary World, 8(4): 527531. 
Singh, H. and Bhat, P. N. 1980. Beta lactglobulin polymorphism in indigenous cattle. Indian Journal of Animals Science, 50: 932- 37.

Sodhi, M., Mukesh, M. and Bhatia, S. 2005. Characterising Nali and Chokla sheep differentiation with microsatellite markers. Small Ruminant Res., 65 (3): 185-92.

Sunnucks, P. 2000. Efficient genetic markers for population biology. Trends in Ecology and Evolution, 15: 199-203.

Toro, M. A., Fernandez, J. and Caballero, A. 2009. Molecular characterization of breeds and its use in conservation. Livestock Science, 120: 174- 195.

Toth, G., Gaspari, Z. and Jurka, J. 2000. Microsatellites in different eukaryotic genomes: Survey and analysis. Genome Research, 10: 967-981.

VanZeveran, A., Peelman, L., Van de Weghe, A. and Bouquet, Y. 1995. A genetic study of four Belgian pig populations by means of seven microsatellite loci. J. Anim. Breed Genet. 112: 191-204.

Verma, N. K., Dixit, S. P. and Ahlawat, S. P. S. 2005. Jakhrana Goat A precious dairy germplasm of semi-arid region. Indian Dairyman, 57: 63-67.

Verma, N.K., Dixit, S.P., Aggarwal, R.A.K.,
Dangi, P.S. and Joshi, B.K. 2010. Phenotypic and genetic characterization of sangamneri goat breed. The Indian J. Anim. Sci., 80: 1109-1114.

Vij, P. K., Tantia, M. S. and Vijh, R. K. 2006. Characterization of Punjab Brown chicken. Animal Genetic Resources Information, 39: 65-76.

Yadav, D. K. and Arora, R. 2014. Genetic discrimination of Muzaffarnagri and Munjal sheep of northwestern semi-arid zone of India based on microsatellite markers and morphological traits. Indian Journal of Animal Sciences, 84(5): 527-532.

Zaman, G. U., Nahardeka, N., Laskar, S., Ferdoci, A. M. and Chetri, A. J. 2013. Molecular characterization of Assam hill goat. American Journal of Animal and Veterinary Sciences, 8(2): 98-103.

Zhong, T., Han, J. L., Guo, J., Zhao, Q. J., Fu, B. L., Pu, Y. B., He, X. H., Jeon, J. T., Guan, W. J. and Ma, Y. H. 2011. Tracing genetic differentiation of Chinese Mongolian sheep using microsatellites. International Foundation for Animal Genetics, 42: 563-565.

\section{How to cite this article:}

Peer Mohmmad Azhar, D. Chakraborty, Zaffar Iqbal, Abrar A. Malik, Ajaz qaudir, Arshaq Asfar and Imtiyaz Ahmad Bhat. 2018. Microsatellite Markers as a Tool for Characterization of Small Ruminants: A Review. Int.J.Curr.Microbiol.App.Sci. 7(01): 1330-1342. doi: https://doi.org/10.20546/ijcmas.2018.701.162 